\title{
Zinc alleviates cadmium induced heavy metal stress by stimulating antioxidative defense in soybean [Glycine max (L.) Merr.] crop
}

\author{
Dhiraj Kapur \\ Department of Botany, Panjab University, Chandigarh (160014), India \\ Kamal Jit Singh* \\ Department of Botany, Panjab University, Chandigarh (160014), India \\ *Corresponding author. E-mail: kamal@pu.ac.in
}

\section{Article Info}

DOI: 10.31018/jans.v11i2.2054

Received: April 4, 2019

Revised: May 3, 2019

Accepted: May 6, 2019

\section{How to Cite}

Kapur, D. and Singh, K.J. (2019). Zinc alleviates cadmium induced heavy metal stress by stimulating antioxidative defense in soybean [Glycine max (L.) Merr.] crop. Journal of Applied and Natural Science, 11(2): 338- 345 https://doi.org/10.31018/ jans.v11i2.2054 accumulation behavior of other non-enzymatic metabolites like MDA, proline and ascorbic acid also get reversed with metal combination treatment. Moreover, the efficacy of $\mathrm{Zn}$ was more when applied in higher concentrations with low $\mathrm{Cd}$. Thus, $\mathrm{Zn}$ plays a key role in plants to counter heavy metal stress by elevating antioxidative defense with higher activity of enzymes and reduced levels of non-enzymatic metabolites, and efficacy of $\mathrm{Zn}$ in combination is dose dependent.

Keywords: Abiotic stress, Antagonistic interactions, Grains, Legumes, Pulses

\section{INTRODUCTION}

Cadmium (Cd) is a toxic heavy metal that occurs naturally in soil with no known biological function in the plants and animals. Various anthropogenic activities are mainly responsible for a range of issues such as over exploitation of resources, salinity, acidification and contamination by metal pollutants. Such activities have dangerously added to the chances of entry of heavy metals into our ecological food chains and risking human health (Lantzy and Mackenzie, 1979; Galloway et al., 1982; Angelone and Bini, 1992). Many such metal elements with no metabolic function greatly reduce the crop productivity in their supra-optimal range (Rascio and Navari-Izzo, 2011; Pierart et al., 2015). And more seriously, such heavy metals exhibit very high stability rate in soil due to lack of biodegradability (Smolders et al., 1999; Singh and Prasad, 2015). Various negative effects of such metals have been reported affecting the development of roots and shoots (Lux et al., 2011; Gallego et al., 2012). Cadmium accumulation interferes with the enzymes of Calvin cycle, carbo- hydrate metabolism, photosynthesis (Shi et al., 2010) and alters the antioxidant metabolism (Khan et al., 2009). Cd triggers the oxidation of NADPH resulting in extracellular production of toxic superoxide $\left(\mathrm{O}_{2}{ }^{--}\right)$and accumulation of $\mathrm{H}_{2} \mathrm{O}_{2}$ (Kawano et al., 2001; Brahim et al., 2010). Destabilization of cell membrane enhances due to generation of ROS causing lipid peroxidation (Smeets et al., 2005). Such oxidation effects can be controlled with the stimulation of antioxidant enzymes and non-enzymatic metabolites via ascorbateglutathione cycle (Foyer and Noctor, 2003). Depending upon the severity of metal toxicity, response of antioxidant machinery varies among species and different tissues (Hassan et al., 2005a). The defense response is essentially related to metal ion acquisition and ion homeostasis for the survival of plants, pathogens and herbivores (Morkunas et al., 2018).

$\mathrm{Zn}$, an essential micronutrient actively participates in various biological functions such as cell membrane integrity, chlorophyll biosynthesis, photosynthesis, enzyme activation, carbohydrate metabolism, fertility, protein synthesis, gene expres- 
sion and regulation (Nishizawa, 2005; Broadley et al., 2007; Chasapis et al., 2012; Marschner and Marschner, 2012). Structurally, it is an integral component of more than 300 enzymes including RNA polymerase, alcohol dehydrogenase, alkaline phosphatase and carbonic anhydrase (Guerinot and Eide, 1999; Auld, 2001). Zn protects the vital components of cell such as chlorophyll, membrane lipids and -SH group of proteins against ROS (Cakmak, 2000). Zn fertilization is thus, necessary to protect the plant cell from oxidative damage being a cofactor of antioxidative enzyme SOD (Alscher et al., 2002; Alloway, 2004). Processing and the subsequent release of zinc to environment is normally accompanied by cadmium as pollutant (Ullrich et al., 1999) because, generally zinc ores $(\mathrm{ZnS})$ contain upto $5 \%$ or even more of cadmium (Adriano, 1986). Due to their chemical similarity both $\mathrm{Cd}$ and $\mathrm{Zn}$ are taken up by plants as divalent cation and compete at the plasma membrane (Hart et al., 2002). In yeast cells, the intake of $\mathrm{Cd}$ occurs through $\mathrm{Zn}$ carrier proteins at the plasma membrane (Gomes et al., 2002). Looking at the present information, it was thought worthwhile to study the role of $\mathrm{Zn}$ in ameliorating heavy metal $\mathrm{Cd}$ induced stress by assessing activity of both enzymatic and nonenzymatic antioxidants in soybean crop.

\section{MATERIALS AND METHODS}

Soybean (Glycine max (L.) Merr. Palam soya) seeds were procured from Himachal Pradesh Agriculture University, Palampur, Himachal Pradesh, India. Healthy seeds were surface sterilized with $0.01 \% \mathrm{HgCl}_{2}$ followed by thorough washing with distilled water and overnight soaking in thick slurry of rhizobium culture mixed with activated charcoal and acacia gum. The plants were raised in earthenware pots filled with approximately $5 \mathrm{~kg}$ of washed river sand and were lined with perforated polythene bags. Only three healthy plants were selected after thinning in each pot. The plants were grown and maintained in natural daylight conditions in dome shaped out-house. $\mathrm{Cd}\left(\mathrm{Cd}_{0.3}\right.$

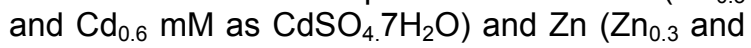
$\mathrm{Zn}_{0.8} \mathrm{mM}$ as $\mathrm{ZnSO}_{4} .7 \mathrm{H}_{2} \mathrm{O}$ ) treatments were given 8 DAS (days after sowing) alone and in combination along with the nutrient medium (Minchin and Pate, 1975). Plants irrigated with distilled water served as control. The observations were recorded at the reproductive stage using fresh leaves.

Standardized procedure was followed for the measurements of MDA content (Heath and Packer, 1968) using extinction coefficient $155 \mathrm{mM}^{-1} \mathrm{~cm}^{-}$ , $\mathrm{H}_{2} \mathrm{O}_{2}$ (Velikova et al., 2000), Ascorbic acid (Mukherji and Chaudhari, 1983) and Proline (Bates et al., 1973). The activity of enzymes was assayed by method of Nakano and Asada, 1981 (APX activity) using molar extinction coefficient $2.8 \mathrm{mM}^{-1} \mathrm{~cm}^{-1}$, Teranishi et al., 1974 (CAT) using molar extinction coefficient $36 \mathrm{mM}^{-1} \mathrm{~cm}^{-1}$, Mavis and Stellwagen, 1968 (GR), Dhindsa et al., 1981 (SOD) and one unit of SOD activity was defined as the amount of enzyme causing $50 \%$ inhibition of photochemical reduction of NBT.

Statistical analysis: All the values were in triplicates and represented as mean \pm SE (standard error). Data was statistically analysed using oneway ANOVA in SPSS-16 by taking the probability level of $5 \%$. Least significant difference (LSD) post hoc test was used to compare the multiple comparisons of mean.

\section{RESULTS}

Malondialdehyde (MDA) content: MDA content increased to $26.81 \%$ and $41.16 \%$ in $\mathrm{Cd}_{0.3}$ and $\mathrm{Cd}_{0.6} \mathrm{mM}$ treatments to that of control. $\mathrm{Zn}$ alone and in all combination treatments with $\mathrm{Cd}$ reduced the enhanced MDA content. In $\mathrm{Zn}_{0.3}$ and $\mathrm{Zn}_{0.8}$ $\mathrm{mM}$ alone treatment, MDA content was lowered by $7.25 \%$ and $23.50 \%$ in comparison to control, respectively. In combined treatments $\mathrm{Zn}$ supplementation decreased MDA content to $0.78 \%$ and $17.82 \%$ in $\mathrm{Cd}_{0.3}+\mathrm{Zn}_{0.3} \mathrm{mM}$ and $\mathrm{Cd}_{0.3}+\mathrm{Zn}_{0.8} \mathrm{mM}$; to $9.30 \%$ in $\mathrm{Cd}_{0.6}+\mathrm{Zn}_{0.8} \mathrm{mM}$ in comparison to control. Similarly in $\mathrm{Cd}_{0.6}+\mathrm{Zn}_{0.3} \mathrm{mM}$ treatment, $\mathrm{Zn}$ was able to reduce the MDA content to some extent in which MDA content was $15.14 \%$ more than that of control. Thus, $\mathrm{Zn}$ supplementation was effective in lowering MDA content in Cd treated plants (Fig. 1a).

Proline content: The content of proline, known osmoprotectant was enhanced upto $20.33 \%$ and $35.16 \%$ in $\mathrm{Cd}_{0.3}$ and $\mathrm{Cd}_{0.6} \mathrm{mM}$ treatments in comparison to control. $\mathrm{Zn}$ combination was able to check proline accumulations with a rise of only $13.55 \%$ and $1.69 \%$ in $\mathrm{Cd}_{0.3}+\mathrm{Zn}_{0.3} \mathrm{mM}$ and $\mathrm{Cd}_{0.3}+\mathrm{Zn}_{0.8} \mathrm{mM} ; 27.54 \%$ and $6.77 \%$ in $\mathrm{Cd}_{0.6}+\mathrm{Zn}_{0.3}$ $\mathrm{mM}$ and $\mathrm{Cd}_{0.6}+\mathrm{Zn}_{0.8} \mathrm{mM}$ treatments, respectively. In $\mathrm{Zn}_{0.3}$ and $\mathrm{Zn}_{0.8} \mathrm{mM}$ alone treatments, a drop in proline content upto $2.96 \%$ and $10.59 \%$ was observed. It was noticed that higher concentration of $\mathrm{Zn}(0.8 \mathrm{mM})$ in combination was more effective in restoring proline levels (Fig. $1 \mathrm{~b}$ ).

Hydrogen peroxide $\left(\mathrm{H}_{2} \mathrm{O}_{2}\right)$ : The content of hydrogen peroxide, another parameter related to oxidative stress increased by $25.02 \%$ and $38.56 \%$ in $\mathrm{Cd}_{0.3}$ and $\mathrm{Cd}_{0.6} \mathrm{mM}$ in comparison to control. $\mathrm{Zn}$ supplementation in combination treatments checked such accumulation with a rise of only 13.81\%, 4.57\% in $\mathrm{Cd}_{0.3}+\mathrm{Zn}_{0.3} \mathrm{mM}$ and $\mathrm{Cd}_{0.3}+\mathrm{Zn}_{0.8}$ $\mathrm{mM}$; and $31.66 \%, 19.19 \%$ in $\mathrm{Cd}_{0.6}+\mathrm{Zn}_{0.3} \mathrm{mM}$ and $\mathrm{Cd}_{0.6}+\mathrm{Zn}_{0.8} \mathrm{mM}$ treatments, respectively. In $\mathrm{Zn}_{0.3}$ and $\mathrm{Zn}_{0.8} \mathrm{mM}$ alone treatments, reduction in $\mathrm{H}_{2} \mathrm{O}_{2}$ level was noticed upto $3.41 \%$ and $18.74 \%$, respectively. Efficacy of $\mathrm{Zn}$ was more when used in higher concentrations (Fig. 1c).

Ascorbic acid (AsA): There was a drop of $43.57 \%$ and $52.79 \%$ in level of Ascorbic acid with $\mathrm{Cd}_{0.3}$ and $\mathrm{Cd}_{0.6} \mathrm{mM}$ treatments in comparison to 
Kapur, D. and Singh, K.J. / J. Appl. \& Nat. Sci. 11(2): 338- 345 (2019)
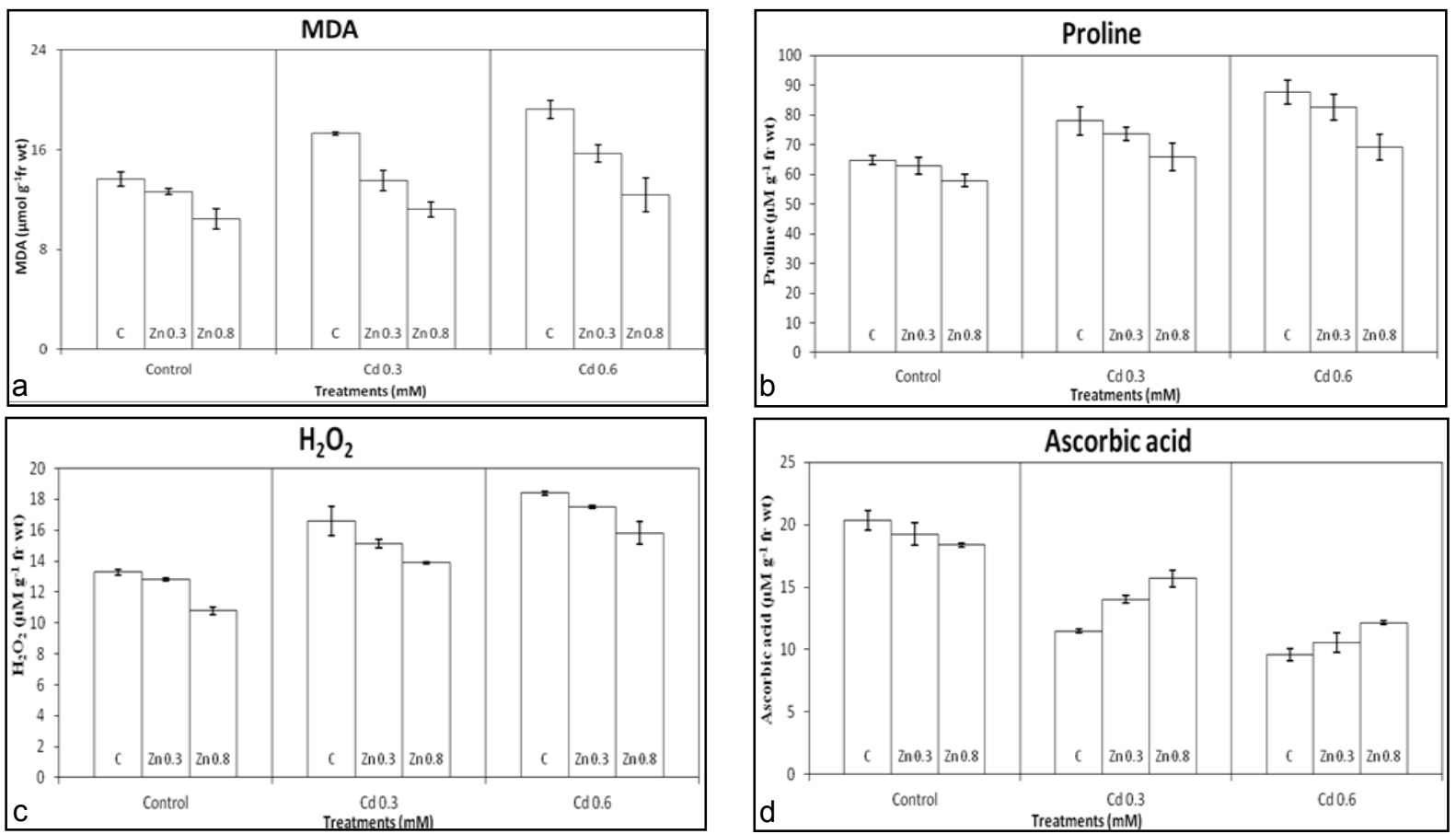

Fig. 1. Effect of $\mathrm{Cd}$ and $\mathrm{Zn}$ alone and in combination on (a) $M D A$ content $\left(L S D_{0.05}=2.18\right)$, (b) Proline content $\left(L S D_{0.05}=10.71\right)$, (c) Hydrogen peroxide content $\left(L S D_{0.05}=1.25\right)$, (d) Ascorbic acid content $\left(L S D_{0.05}=1.68\right)$ in soybean plants. Each value represents mean $\pm S E$ of three replicates.
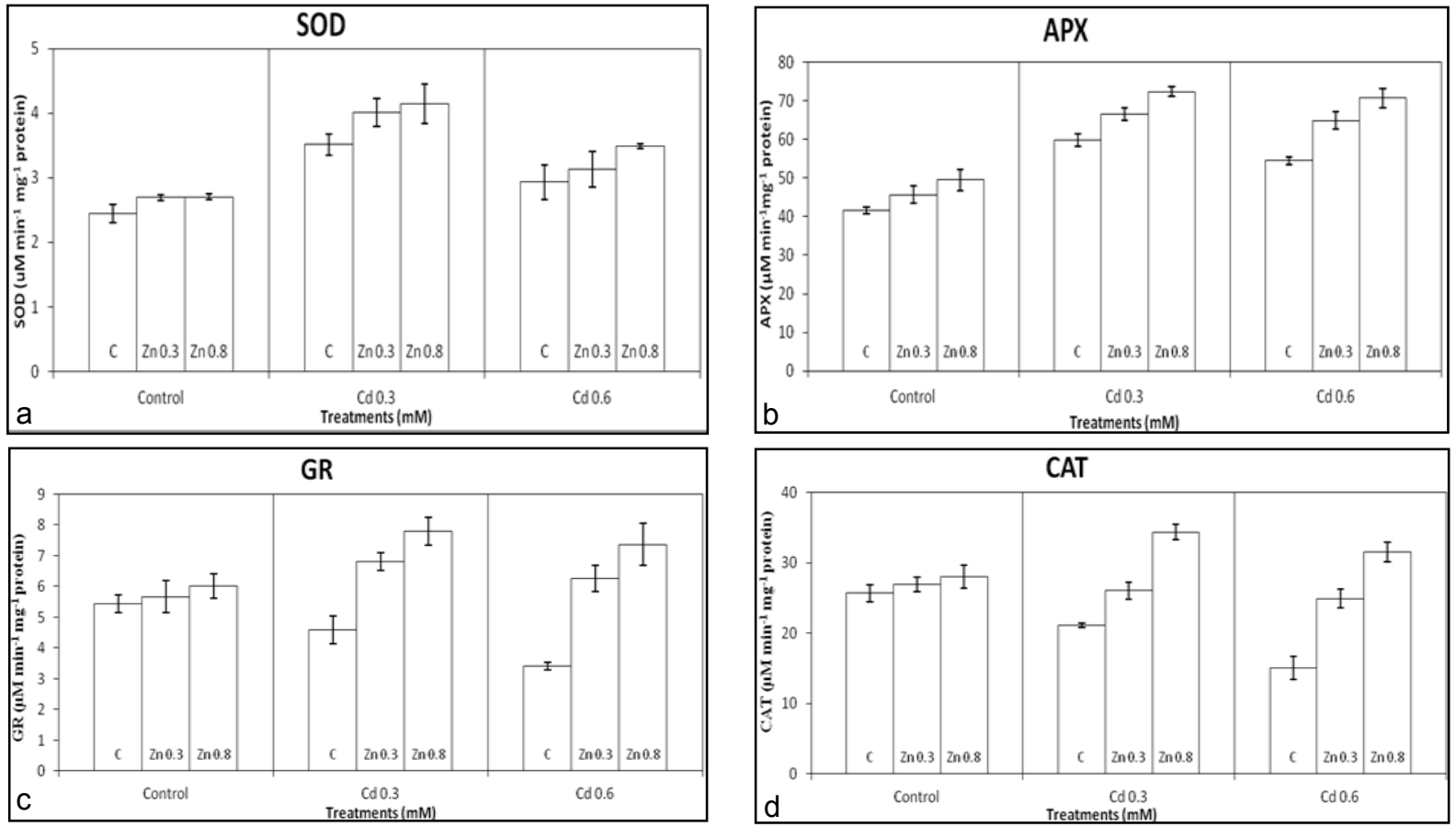

Fig. 2. Effect of $\mathrm{Cd}$ and $\mathrm{Zn}$ alone and in combination on (a) Sodium dismutase activity $\left(L S D_{0.05}=0.58\right)$, (b) Ascorbate peroxidase activity $\left(L S D_{0.05}=5.57\right)$, (c) Glutathione reductase activity $\left(L S D_{0.05}=1.27\right)$, (d) Catalase activity $\left(L S D_{0.05}=3.74\right)$ in soybean plants. Each value represents mean $\pm S E$ of three replicates.

control. Even, $\mathrm{Zn}_{0.3}$ and $\mathrm{Zn}_{0.8} \mathrm{mM}$ alone treatments had decreased AsA contents upto 5.41 and $9.71 \%$. $\mathrm{Zn}$ combination checked such losses to $31.07 \%, 22.96 \%$ in $\mathrm{Cd}_{0.3}+\mathrm{Zn}_{0.3} \mathrm{mM}, \mathrm{Cd}_{0.3}+\mathrm{Zn}_{0.8}$
$\mathrm{mM}$; and to $48.12 \%, 40.29 \%$ in $\mathrm{Cd}_{0.6}+\mathrm{Zn}_{0.3} \mathrm{mM}$ and $\mathrm{Cd}_{0.6}+\mathrm{Zn}_{0.8} \mathrm{mM}$ treatments, respectively. Efficacy of $\mathrm{Zn}$ treatment was more with lower concentrations of heavy metal Cd (Fig. 1d). 
Superoxide dismutase (SOD) activity: The activity of enzyme SOD was enhanced by $10.10 \%$ and $10.61 \%$ in $\mathrm{Zn}_{0.3}$ and $\mathrm{Zn}_{0.8} \mathrm{mM}$, alone treatments, respectively in comparison to control. Cd treatment had also raised its activity upto $43.66 \%$ $\left(\mathrm{Cd}_{0.3} \mathrm{mM}\right)$ and $19.88 \%\left(\mathrm{Cd}_{0.6} \mathrm{mM}\right)$ of the control values. In combination treatment, the activity was further raised upto $64.05 \%$ and $69.05 \%$ in $\mathrm{Cd}_{0.3}+\mathrm{Zn}_{0.3} \mathrm{mM}$ and $\mathrm{Cd}_{0.3}+\mathrm{Zn}_{0.8} \mathrm{mM}$; and upto $28.03 \%$ and $42.8 \%$ in $\mathrm{Cd}_{0.6}+\mathrm{Zn}_{0.3}$ and $\mathrm{Cd}_{0.6}+\mathrm{Zn}_{0.8}$ $\mathrm{mM}$, respectively (Fig. 2a).

Ascorbate peroxidase (APX) activity: APX enzyme activity enhanced upto $43.9 \%\left(\mathrm{Cd}_{0.3} \mathrm{mM}\right)$ and $31.05 \%$ in $\left(\mathrm{Cd}_{0.6} \mathrm{mM}\right)$ in comparison to control. Even, $\mathrm{Zn}$ alone treatment resulted in an increase of $9.89\left(Z_{0.3} \mathrm{mM}\right)$ and $19.17 \%\left(Z \mathrm{n}_{0.8} \mathrm{mM}\right)$. $\mathrm{Zn}$ in combination treatments with $\mathrm{Cd}$ further raised its activity upto $59.97 \%$ and $74.18 \%$ in $\mathrm{Cd}_{0.3}+\mathrm{Zn}_{0.3} \mathrm{mM}$ and $\mathrm{Cd}_{0.3}+\mathrm{Zn}_{0.8} \mathrm{mM}$; and upto 56.13 and $70.16 \%$ in $\mathrm{Cd}_{0.6}+\mathrm{Zn}_{0.3} \mathrm{mM}$ and $\mathrm{Cd}_{0.6}+\mathrm{Zn}_{0.8} \mathrm{mM}$ treatments, respectively (Fig. $2 \mathrm{~b}$ ). Glutathione reductase (GR) activity: Activity of GR was reduced with an increase in $\mathrm{Cd}$ treatment. The decrease was upto $15.46 \%\left(\mathrm{Cd}_{0.3} \mathrm{mM}\right)$ and $37.45 \%\left(\mathrm{Cd}_{0.6} \mathrm{mM}\right)$ to that of control. $\mathrm{Zn}$ supplementation had a positive effect in raising enzyme activity levels. Zn supplementation in combination treatments raised activity levels upto $25.09 \%$ and $43.26 \%$ in $\mathrm{Cd}_{0.3}+\mathrm{Zn}_{0.3} \mathrm{mM}$ and $\mathrm{Cd}_{0.3}+\mathrm{Zn}_{0.8} \mathrm{mM}$; and $14.94 \%$ and $35.55 \%$ in $\mathrm{Cd}_{0.6}+\mathrm{Zn}_{0.3} \mathrm{mM}$ and $\mathrm{Cd}_{0.6}+\mathrm{Zn}_{0.8} \mathrm{mM}$ treatments, respectively (Fig. 2c).

Catalase (CAT) activity: Cadmium treatment caused sharp drop in activity of enzyme CAT was upto $17.67 \%\left(\mathrm{Cd}_{0.3} \mathrm{mM}\right)$ and $41.24 \%\left(\mathrm{Cd}_{0.6} \mathrm{mM}\right)$ in comparison to control. $\mathrm{Zn}$ alone application was promotory in raising activity up by $4.97 \%\left(\mathrm{Zn}_{0.3}\right.$ $\mathrm{mM})$ and $9.17 \%\left(\mathrm{Zn}_{0.8} \mathrm{mM}\right)$. $\mathrm{Zn}$ in combination treatment checked the drop in enzyme activity to $1.46 \%$ in $\mathrm{Cd}_{0.3}+\mathrm{Zn}_{0.3} \mathrm{mM}$ and $2.89 \%$ in $\mathrm{Cd}_{0.6}+\mathrm{Zn}_{0.3}$ mM. In $\mathrm{Cd}_{0.3}+\mathrm{Zn}_{0.8} \mathrm{mM}$ and $\mathrm{Cd}_{0.6}+\mathrm{Zn}_{0.8} \mathrm{mM}$ the activity was enhanced upto $33.82 \%$ and $22.99 \%$ in comparison to control (Fig. 2d).

\section{DISCUSSION}

Our findings clearly revealed that soybean plants countered heavy metal $\mathrm{Cd}$ induced oxidative stress through enzymatic and non-enzymatic activity of metabolites. Higher levels of Cd stimulates the activity of potential enzymes like APX, SOD accompanied by accumulated contents of nonenzymatic metabolites, $\mathrm{H}_{2} \mathrm{O}_{2}$, MDA and proline as a marker of rise in oxidative stress of plants. Such multiple responses were due to production of the reactive oxygen species (ROS), and were indicative of plant being under oxidative stress (Ahmed et al., 2008, 2010). Cd induced oxidative stress negatively affect the defense system of wheat with an overproduction of ROS (Qayyum et al., 2017; Hussain et al., 2018; Rehman et al., 2018). Pro- line accumulation is considered as one of the most sensitive response to abiotic stress including heavy metal Cd (Ashraf and Harris, 2004; Chen et al., 2004; Mishra and Dubey, 2006; Kalai et al., 2014). Lipid peroxidation occurs as malondialdehyde content (MDA) enhances with $\mathrm{Cd}$ treatment (Singh et al., 2006, Tkalec et al., 2014; Kapoor et al., 2016). Also, the reduced activity of CAT, GR and ascorbic acid content was based upon level of Cd treatment. SOD can convert $\mathrm{O}_{2}{ }^{--}$to $\mathrm{H}_{2} \mathrm{O}_{2}$ while CAT decomposes $\mathrm{H}_{2} \mathrm{O}_{2}$ to $\mathrm{H}_{2} \mathrm{O}$ and oxygen molecules, and similarly other antioxidant enzymes also play role in ROS scavenging in plants (Mittler, 2002). Higher concentration of $\mathrm{O}_{2}$ inactivates the enzyme CAT (Cakmak, 2000) while GR is highly sensitive to inhibition by heavy metals ions (Smith et al., 1989). Various genes were differentially regulated in response to abiotic stress to induce a similar kind of defense response resulting in the enhanced levels of several metabolites and proteins (Ozturk et al., 2002).

$\mathrm{Zn}$ plays a vital role in production and activity of enzymes to detoxify the reactive oxygen species (Tavallali et al., 2010; Weisany et al., 2012). In the present studies enhanced activity of such enzymes like APX, GR, CAT and SOD was noticed in $\mathrm{Cd}-\mathrm{Zn}$ combination. Higher activity of SOD, CAT, APX and GR in Cd and Zn combinations was due to $\mathrm{Zn}$ against heavy metal induced oxidative stress in Ceratophyllum demersum (Aravind and Prasad, 2003, 2005).

Similar findings have also reported that the reduced activity of SOD, CAT, APX and GR during oxidative stress was up-regulated by lower concentrations of $\mathrm{Zn}$ (Cherif et al., 2011). Foliar spray of $\mathrm{ZnO}$ nanoparticles reduce electrolyte leakage, MDA and $\mathrm{H}_{2} \mathrm{O}_{2}$ content; raising the content of chlorophyll and activities of SOD, CAT, APX and POD in maize crop grown in Cd contaminated soil (Rizwan et al., 2019). Zn supplementation inhibited NADPH oxidation and formation of $\mathrm{O}_{2}{ }^{-}$radical to prevent the formation of ROS in $\mathrm{Cd}$ treated plants (Aravind et al., 2009, Cherif et al., 2011). $\mathrm{Zn}$ supplemented $\mathrm{Cd}$ plants promotes the APX activity to control $\mathrm{H}_{2} \mathrm{O}_{2}$ levels thus, preventing cell damage more efficiently (Asada, 1992; Shigeoka et al., 2002; Dikkaya and Ergün, 2014). As reported earlier, our results have also indicated the depletion in $\mathrm{H}_{2} \mathrm{O}_{2}$ levels with $\mathrm{Zn}$ combination treatment (Cho and Seo, 2005; Mobin and Khan, 2006; Markovaska et al., 2009; Gill et al., 2012). As, Zn alone treatment in plants did not show any significant change in the activities of SOD, CAT, APX and GR indicating toxicity effects due to $\mathrm{Cd}$ treatments only (Arvind and Prasad, 2003; Cherif et al., 2011). Other non-enzymatic metabolites like MDA, proline and ascorbic acid also reversed their accumulation behavior in $\mathrm{Zn}$ supplemented $\mathrm{Zn}-\mathrm{Cd}$ combination treatment compared to $\mathrm{Cd}$ only treatments. Addition of $\mathrm{Zn}$ to $\mathrm{Cd}$ stressed plants helps 
in lowering MDA content and proline accumulations (Khalid and Hendawy, 2005; Subba et al., 2014; Qiao et al. 2015). Zn supplementation lowers the abiotic stress including that of heavy metal Cd by raising ascorbic acid levels (Ozturk et al., 2003, Ma et al., 2017; Seminario et al., 2017). Zn stabilizes and protects the bio-membrane proteins and phospholipids from the oxidative damage (Powell, 2000). An antagonistic interaction between $\mathrm{Cd}$ and $\mathrm{Zn}$ lowers the heavy metal $\mathrm{Cd}$ induced oxidative stress and its accumulation in plants (Wu and Zhang, 2002; Hassan et al., 2005b; Akay and Koleli, 2007; Sarwar et al., 2010; Balen et al., 2011; Trakal et al., 2012). Moreover, it was also noticed that efficacy of the $\mathrm{Zn}$ in combination treatment was more when $\mathrm{Cd}$ was in lower concentrations.

\section{Conclusion}

Heavy metal cadmium exposure induces an oxidative stress in soybean plants. Zn treatment effectively protects the plant from heavy metal stress by lowering the accumulation of stress related metabolites, inhibiting membrane lipid peroxidation and enhancing activity of enzymes that play vital role in ROS scavenging. Efficacy of $\mathrm{Zn}$ supplementation in combination treatment is dose dependent and more with lower $\mathrm{Cd}$ concentrations.

\section{ACKNOWLEDGEMENTS}

The authors are grateful to DST (Department of Science and Technology, New Delhi, India) Purse Grant for financial assistance.

\section{REFERENCES}

1. Adriano, D.C. (1986). Trace elements in the terrestrial environment. Springer-Verlag, New York.

2. Ahmad, P., Jaleel, C.A., Salem, M.A., Nabi, G. and Sharma, S. (2010). Roles of enzymatic and nonenzymatic antioxidants in plants during abiotic stress. Critical Reviews in Biotechnology, 30: 161175. https://doi.org/10.3109/07388550903524243

3. Ahmad, P., Sarwat, M. and Sharma, S. (2008). Reactive oxygen species, antioxidants and signaling in plants. Journal of Plant Biology, 51: 167-173. https:// doi.org/10.1007/BF03030694

4. Akay, A. and Koleli, N. (2007). Interaction between cadmium and zinc in barley (Hordeum vulgare L.) grown under field conditions. Bangladesh Journal of Botany, 36: 13-19. https://doi.org/10.3329/ bjb.v36i1.1543

5. Alloway, B.J. (2004). Zinc in Soils and Crop Nutrition. Publ. of International Zinc Association.

6. Alscher, R.G., Erturk, N. and Heath, L.S. (2002). Role of superoxide dismutase (SODs) in controlling oxidative stress in plants. Journal of Experimental Botany, 53: 1331-1341.

7. Angelone, M. and Bini, C. (1992). Trace elements concentrations in soils and plants of Western Europe. In: (Adriano DC, ed.) Biogeochemistry of trace metals. Boca Raton, FL: Lewis Publishers, 19-60.
8. Aravind, P. and Prasad, M.N.V. (2003). Zinc alleviates cadmium induced oxidative stress in Ceratophyllum demersum L.: A free floating freshwater macrophyte. Plant Physiology and Biochemistry, 41: 391397. https://doi.org/10.1016/S0981-9428(03)00035-4

9. Aravind, P. and Prasad, M.N.V. (2005). Modulation of cadmium-induced oxidative stress in Ceratophyllum demersum by zinc involves ascorbate-glutathione cycle and glutathione metabolism. Plant Physiology and Biochemistry, 43: 107-116. https:// doi.org/10.1016/j.plaphy.2005.01.002.

10.Aravind, P., Prasad, M.N.V., Malec, P., Waloszek, A. and Strzał-ka, K. (2009). Zinc protects Ceratophyllum demersum L. (free-floating hydrophyte) against reactive oxygen species induced by cadmium. Journal of Trace Elements in Medicine and Biology, 23: 50-60. https://doi.org/10.1016/j.jtemb.2008.10.002

11.Asada, K. (1992). Ascorbate peroxidase-a hydrogen peroxide scavenging enzyme in plants. Physiologia Plantarum, 85: 235-241. https://doi.org/10.1111/ j.1399-3054.1992.tb04728.x

12.Ashraf, M. and Harris, P.J.C. (2004). Potential biochemical indicators of salinity tolerance in plants. Plant Science, 166: 3-16. https://doi.org/10.1016/ j.plantsci.2003.10.024

13.Auld, D.S. (2001). Zinc coordination sphere in biochemical zinc sites. Biometals, 14: 271-313.

14.Balen, B., Tkalec, M., Šikić, S., Tolić, S., Cvjetko, P., Pavlica, M. and Vidakovic'-Cifrek, Z. (2011). Biochemical responses of Lemna minor experimentally exposed to cadmium and zinc. Ecotoxicology, 20: 815-826. https://doi.org/10.1007/s10646-011-0633-1

15.Bates, L.S., Waldren, R.P. and Teare, I.D. (1973). Rapid determination of free proline for water stress studies. Plant Soil, 39: 205-207. https:// doi.org/10.1007/BF00018060

16.Brahim, S., Joke, D., Ann, C., Jean-Paul, N., Marjo, T., Arja, T., Sirpa, K., Frank, V.B., Karen, S. and Jaco, V. (2010). Leaf proteome responses of Arabidopsis thaliana exposed to mild cadmium stress. Journal of Plant Physiology, 167(4): 247-254. https:// doi.org/10.1016/j.jplph.2009.09.015

17.Broadley, M.R., White, P.J., Hammond, J.P., Zelko, I. and Lux, A. (2007). Zinc in plants. New Phytologist, 173: 677-702. https://doi.org/10.1111/j.14698137.2007.01996.x

18.Cakmak, I. (2000). Possible roles of zinc in protecting plant cells from damage by reactive oxygen species. New Phytologist, 146: 185-205. http:// dx.doi.org/10.1046/j.1469-8137.2000.00630.x

19.Chasapis, C.T., Loutsidou, A.C., Spiliopoulou, C.A. and Stefanidou, M.E. (2012). Zinc and human health: an update. Archives of Toxicology, 86: 521534. https://doi.org/10.1007/s00204-011-0775-1

20.Chen, C.T., Chen, T.H., Lo, K.F. and Chiu, C.Y. (2004). Effects of proline on copper transport in rice seedlings under excess copper stress. Plant Science, 166: 103-111.

21.Cherif, J., Mediouni, C., Ammar, W. and Jemal, F. (2011). Interactions of zinc and cadmium toxicity in their effects on growth and in antioxidative systems in tomato plants (Solanum lycopersicum). Journal of Environmental Science, 23: 837-844.

22.Cho, Un-H. and Seo, Nam-H. (2005). Oxidative stress in Arabidopsis thaliana exposed to cadmium is due to hydrogen peroxide accumulation. Plant Science, 168: 113-120. https://doi.org/10.1016/ 
j.plantsci.2004.07.021

23.Dhindsa, R.S., Plumb-Dhindsa, P. and Thorpe, T.A. (1981). Leaf senescence: correlated with increased level of membrane permeability and lipid peroxidation and decreased level of superoxide dismutase and catalase. Journal of Experimental Botany, 23: 93101. https://doi.org/10.1093/jxb/32.1.93

24.Dikkaya, E.T. and Ergün, N. (2014). Effects of cadmium and zinc interactions on growth parameters and activities of ascorbate peroxidase on maize (Zea mays L. MAT 97). European Journal of Experimental Biology, 4(1): 288-295.

25.Foyer, C.H. and Noctor, G. (2003). Redox sensing and signalling associated with reactive oxygen in chloroplasts, peroxisomes and mitochondria. Physiologia Plantarum, 119: 355-364. https:// doi.org/10.1034/j.1399-3054.2003.00223.x

26.Gallego, S.M., Pena, L.B., Barcia, R.A., Azpiliceuta, C.E., lannone, M.F., Rosales, E.P., Zawoznik, M.S., Groppa, M.D. and Benavides, M.P. (2012). Unraveling cadmium toxicity and tolerance in plants: insight into regulatory mechanisms. Environmental and Experimental Botany, 83: 33-46. https://doi.org/10.1016/ j.envexpbot.2012.04.006

27.Galloway, J.N., Thornton, J.D., Norton, S.A., Volcho, H.L. and McLean, R.A. (1982). Trace metals in atmospheric deposition: a review and assessment. Atmospheric Environement, 16: 1677-1700. https:// doi.org/10.1016/0004-6981(82)90262-1

28.Gill, S.S., Khan, N.A. and Tuteja, N. (2012). Cadmium at high dose perturbs growth, photosynthesis and nitrogen metabolism while at low dose it up regulates sulfur assimilation and antioxidant machinery in garden cress (Lepidium sativum L.). Plant Science, 182: 112-120.

29.Gomes, D.S., Fragoso, L.C., Riger, C.J., Panek, A.D. and Eleutherio, E.C.A. (2002). Regulation of cadmium uptake by Saccharomyces cerevisiae. Biochimica et Biophysica Acta (BBA) Bioenergetics, 1573(1): 2125. https://doi.org/10.1016/S0304-4165(02)00324-0

30.Guerinot, M.L. and Eide, D. (1999). Zeroing in on zinc uptake in yeast and plants. Current Opinion in Plant Biology, 2: 244-249. https://doi.org/10.1016/ S1369-5266(99)80042-9

31.Hart, J.J., Welch, R.M., Norvell, W.A. and Kochian, L.V. (2002). Transport interactions between cadmium and zinc in roots of bread and durum wheat seedlings. Physiologia Plantarum, 116(1):73-78. https:// doi.org/10.1034/j.1399-3054.2002.1160109.x

32. Hassan, M.J., Shao, G. and Zhang, G. (2005a). Influence of cadmium toxicity on antioxidant enzymes activity in rice cultivars with different grain $\mathrm{Cd}$ accumulation. Journal of Plant Nutrition, 28: 1259-1270. https://doi.org/10.1081/PLN-200063298

33.Hassan, M.J., Zhang, G., Wu, F., Wie, K. and Chen, Z. (2005b). Zinc alleviates growth inhibition and oxidative stress caused by cadmium in rice. Journal of Plant Nutrition and Soil Science, 168: 255-261. https://doi.org/10.1002/jpln.200420403

34. Heath, R.L. and Packer, L. (1968). Photoperoxidation in isolated chloroplast-I: Kinetics stoichiometery of fatty peroxidation. Archives of Biochemistry and Biophysics, 125: 189-198. https://doi.org/10.10 16/0 003-9861(68)90654-1

35.Hussain, A., Ali, S., Rizwan, M., Rehman, M.Z., Javed, M.R., Imran, M., Chatha, S.A.S. and Nazir, R. (2018). Zinc oxide nanoparticles alter the wheat physiological response and reduce the cadmium uptake by plants. Environment Pollution, 242: 15181526. https://doi.org/10.1016/j.envpol.2018.08.036

36.Kalai, T., Khamassi, K., Silva, J.A.T.d., Gouia, H. and Ben-Kaab, L.B. (2014). Cadmium and copper stress affect seedling growth and enzymatic activities in germinating barley seeds. Archives of Agronomy and Soil Science, 60(6): 765-783. https:// doi.org/10.1080/03650340.2013.838001

37.Kapoor, D., Rattan, A., Bhardwaj, R., Kaur, S., Gupta, A. and Manoj (2016). Antioxident defence responses and activation of phenolic compounds in Brassica juncea exposed to cadmium stress. International Journal of Green Pharmacy, 10(4): 228-234. http://dx.doi.org/10.22377/ijgp.v10i04.760

38.Kawano, T., Kawano, N., Muto, S. and Lapeyrie, F. (2001). Cation-induced superoxide generation in tobacco cell suspension culture is dependent on ion valence. Plant Cell Environment, 24: 1235-1241. https://doi.org/10.1046/j.1365-3040.2001.00766.x

39.Khalid, K.A. and Hendawy, S.F. (2005). Response of Sage (Salvia Officinalis L.) plants to zinc application under different salinity levels. Journal of Applied Sciences Research, 1(2): 147-155.

40.Khan, N.A., Anjum, N.A., Nazar, R. and Iqbal, N. (2009). Increased activity of ATP-sulfurylase and increased contents of cysteine and glutathione reduce high cadmium-induced oxidative stress in mustard cultivar with high photosynthetic potential. Russian Journal of Plant Physiology, 56(5): 670-677. https://doi.org/10.1134/S1021443709050136

41.Lantzy, R.J. and Mackenzie, F.T. (1979). Atmospheric trace metals: global cycles and assessment of man's impact. Geochimica et Cosmochimica Acta, 43: 511.

42.Lux, A., Martinka, M., Vaculík, M. and White, P.J. (2011). Root responses to cadmium in the rhizosphere: a review. Journal of Experimental Botany, 62: 21-37.

43.Ma, D., Sun, D., Wang, C., Ding, H., Qin, H., Hou, J., Huang, X., Xie, Y. and Guo, T. (2017). Physiological responses and yield of wheat plants in zinc-mediated alleviation of drought stress. Frontiers in Plant Science, 8: 860. https://doi.org/10.3389/fpls.2017.00860

44.Markovska, Y.K., Gorinova, N.I., Nedkovska, M.P. and Miteva, K.M. (2009). Cadmium-induced oxidative damage and antioxidant responses in Brassica juncea plants. Biologia Plantarum, 53(1): 151-154. https://doi.org/10.1007/s10535-009-0023-1

45.Marschner, H. and Marschner, P. (2012). Marschner's mineral nutrition of higher plants, 3rd ed. Academic, London/Waltham.

46.Mavis, R.D. and Stellwagen, E. (1968). Purification and subunit structure of glutathione reductase from baker's yeast. Journal of Biological Chemistry, 243: 809-814.

47.Minchin, F.R. and Pate, J.S. (1975). Effects of water, aeration and salt regime on nitrogen fixation in a nodulated legume: definition of an optimum root environment. Journal of Experimental Botany, 26: 60-80. https://doi.org/10.1093/jxb/26.1.60

48.Mishra, S. and Dubey, R.S. (2006). Inhibition of ribonuclease and protease activities in arsenic exposed rice seedlings: Role of proline as enzyme protectant. Journal of Plant Physiology, 163: 927-936. https:// doi.org/10.1016/j.jplph.2005.08.003

49.Mittler, R. (2002). Oxidative stress, antioxidants and 
stress tolerance. Trends in Plant Science, 7: 405410. https://doi.org/10.1016/S1360-1385(02)02312-9

50.Mobin, M. and Khan, N.A. (2006). Photosynthetic activity, pigment composition and antioxidative response of two mustard (Brassica juncea) cultivars differing in photosynthetic capacity subjected to cadmium stress. Journal of Plant Physiology, 164: 601610. https://doi.org/10.1016/j.jplph.2006.03.003

51.Morkunas, I., Wozniak, A., Mai, V.C., RucinskaSobkowiak, R. and Jeandet, P. (2018). The role of heavy metals in plant response to biotic stress. Molecules, 23(9): 2309-2320. https://doi.org/10.3390/ molecules23092320

52.Mukherji, S.P. and Chaudhari, M.A. (1983). Implications of water stress induced changes in the levels of endogenous ascorbic acid and hydrogen peroxide in Vigna seedlings. Plant Physiology, 58: 166-170. https://doi.org/10.1111/j.1399-3054.1983.tb04162.x

53.Nakano, Y. and Asada, K. (1981). Hydrogen peroxide is scavenged by ascorbate-specific peroxidase in spinach chloroplasts. Plant Cell Physiology, 22: 867880.

54.Nishizawa, N.K. (2005). The uptake and translocation of minerals in rice plants, in Triyaka $\mathrm{K}$, Heong $\mathrm{KL}$ (eds.): Rice is life: Scientific perspectives for the 21st century. IRRI, Manila, Philippines, pp. 90-93.

55.Ozturk, L., Eker, S. and Ozkutlu, F. (2003). Effect of Cadmium on Growth and Concentrations of Cadmium, Ascorbic Acid and Sulphydryl Groups in Durum Wheat Cultivars. Turkish Journal of Agriculture and Forestry, 27: 161-168

56.Ozturk, Z.N., Talame, V., Deyholos, M., Michalowski, C.B., Galbraith, D.W., Gozukirmizi, N., Tuberosa, R. and Bohnert, H.J. (2002). Monitoring large-scale changes in transcript abundance in drought- and salt stressed barley. Plant Molecular Biology, 48: 551573. https://doi.org/10.1023/A:1014875215580

57.Pierart, A., Shahid, M., Sejalon-Delmas, N. and Dumat, C. (2015). Antimony bioavailability: knowledge and research perspectives for sustainable agricultures. Journal of Hazardous Materials, 289: 219-234. https://doi.org/10.1016/j.jhazmat.2015.02.011

58.Powell, S.R. (2000). The antioxidant properties of zinc. Journal of Nutrition, 130: 1447-1454. https:// doi.org/10.1093/jn/130.5.1447S

59.Qayyum, M.F., Rehman, M.Z., Ali, S., Rizwan, M., Naeem, A., Maqsood, M.A., Khalid, H., Rinklebe, J. and Ok, Y.S. (2017). Residual effects of monoammonium phosphate, gypsum and elemental sulfur on cadmium phytoavailability and translocation from soil to wheat in an effluent irrigated field. Chemosphere, 174: 515-523. https://doi.org/10.1016/j.chemosphere. 2017.02.006

60.Qiao, X., Wang, P., Shi, G. and Yang, H. (2015). Zinc conferred cadmium tolerance in Lemna minor $\mathrm{L}$. via modulating polyamines and proline metabolism. Plant Growth Regulators, 77: 1-9. https:// doi.org/10.1007/s10725-015-0027-0

61.Rascio, N. and Navari-Izzo, F. (2011). Heavy metal hyperaccumulating plants: how and why do they do it? And what makes them so interesting? Plant Science, 180: 169-181. https://doi.org/10.1016/ j.plantsci.2010.08.016

62.Rehman, M.Z., Rizwan, M., Khalid, H., Ali, S., Naeem, A., Yousaf, B., Liu, G., Sabir, M. and Farooq, M. (2018). Farmyard manure alone and combined with immobilizing amendments reduced cadmium accumulation in wheat and rice grains grown in field irrigated with raw effluents. Chemosphere, 199: 468476. https://doi.org/10.1016/j.chemosphere. 2018. 02. 030

63.Rizwan, M., Ali, S., Rehman, M.Z., Adrees, M., Arshad, M., Qayyum, M.F., Ali, L., Hussain, A., Chatha, S.A.S. and Imran, M. (2019). Alleviation of cadmium accumulation in maize (Zea mays L.) by foliar spray of zinc oxide nanoparticles and biochar to contaminated soil. Environmental Pollution, 248: 358-367. https://doi.org/10.1016/j.envpol.2019.02.031

64.Sarwar, N., Saifullah, S.S.M., Munir, H.Z., Asif, N., Sadia, B. and Ghulam, F. (2010). Role of mineral nutrition in minimizing cadmium accumulation by plants. Journal of the Science of Food and Agriculture, 90: 925-937. https://doi.org/10.1002/jsfa.3916

65.Seminario, A., Song, L., Zulet, A., Nguyen, H.T., González, E.M. and Larrainzar, E. (2017). Drought Stress Causes a Reduction in the Biosynthesis of Ascorbic Acid in Soybean Plants. Frontiers in Plant Science, 8: $1042 . \quad$ https://doi.org/10.3389/ fpls.2017.01042

66.Shi, G., Liu, C., Cai, Q., Liu, Q. and Hou, C. (2010). Cadmium Accumulation and Tolerance of Two Safflower Cultivars in Relation to Photosynthesis and Antioxidantive Enzymes. Bulletin of Environmental and Contamination Toxicology, 85(3): 256-263. https://doi.org/10.1007/s00128-010-0067-0

67.Shigeoka, S., Ishikawa, T., Tamoi, M., Miyagawa, Y., Takeda, T., Yabuta, Y. and Yoshimura, K. (2002). Regulation and function of ascorbate peroxidase isoenzymes. Journal of Experimental Botany, 53: 1305-1319.https://doi.org/10.1093/jexbot/53.372. 1305

68.Singh, A. and Prasad, S.M. (2015). Remediation of heavy metal contaminated ecosystem: an overview on technology advancement. International Journal of Environmental Science and Technology, 12: 353366. https://doi.org/10.1007/s13762-014-0542-y

69.Singh, S., Eapen, S. and D'Souza, S.F. (2006). Cadmium accumulation and its influence on lipid peroxidation and antioxidative system in an aquatic plant, Bacopa monnieri L. Chemosphere, 62: 233-246. https://doi.org/10.1016/j.chemosphere.2005.05.017

70.Smeets, K., Cuypers, A., Lambrechts, A., Semane, B., Hoet, P., Laere, A.V. and Vangronsveld, J. (2005). Induction of oxidative stress and antioxidative mechanisms in Phaseolus vulgaris after Cd application. Plant Physiology and Biochemistry, 43: 437-444. https://doi.org/10.1016/j.plaphy.2005.03.007

71.Smith, I.K., Vierheller, T.L. and Thorne, C.A. (1989). Proprieties and functions of glutathione reductase in plants. Physiologia Plantarum, 77: 449-456. https:// doi.org/10.1111/j.1399-3054.1989.tb05666.x

72.Smolders, E., Brans, K., Foldi, A. and Merckx, R. (1999). Cadmium fixation in soils measured by isotopic dilution. Soil Science Society of American Journal, 63(1): 78-85. https://doi.org/10.2136/ sssaj1999.03615995006300010013x

73.Subba, P., Mukhopadhyay, M., Mahato, S.K., Bhutia, K.D., Mondal, T.K. and Ghosh, S.K. (2014). Zinc stress induces physiological, ultra-structural and biochemical changes in mandarin orange (Citrus reticulata Blanco) seedlings. Physiology and Molecular Biology of Plants, 20(4): 461-473. https:// doi.org/10.1007/s12298-014-0254-2

74.Tavallali, V., Rahemi, M., Eshgh, S., Kholdebarin, B. 
and Ramezanian, A. (2010). Zinc alleviates salt stress and increases antioxidant enzyme activity in the leaves of pistachio (Pistacia vera L. 'Badami') seedlings. Turkish Journal of Agriculture and Forestry, 34: 349-359.

75.Teranishi, Y., Tanaka, A., Osumi, M. and Fukui, S. (1974). Catalase activity of hydrocarbon utilizing Candida yeast. Agricultural and Biological Chemistry, 38: 1213-1216. https://doi.org/10.1080/0002 1369. 1974.10861301

76.Tkalec, M., Štefanić, P.P., Cvjetko, P., Šikić, S., Pavlica, M. and Balen, B. (2014). The effects of cadmium-zinc interactions on biochemical response in tobacco seedlings and adult plants. PLOS ONE, 9(1): e87582. https://doi.org/10.1371/journal.pone. 00875 82

77.Trakal, L., Komárek, M., Száková, J., Tlustoš, P., Tejnecký, V. and Drábek, O. (2012). Sorption behavior of $\mathrm{Cd}, \mathrm{Cu}, \mathrm{Pb}$, and $\mathrm{Zn}$ and their interactions in phytoremediated soil. International Journal of Phytoremediation, 14: 806-819.
78.Ullrich, S.M., Ramsey, M.H. and Helios-Rybicka, E. (1999). Total and exchangeable concentrations of heavy metal in soils near Bytom, an area of $\mathrm{Pb} / \mathrm{Zn}$ mining and smelting in upper Silesia, Poland. $A p$ plied Geochemistry, 14: 187-196. https:// doi.org/10.1016/S0883-2927(98)00042-0

79.Velikova, V., Yordanov, I. and Edreva, A. (2000). Oxidative stress and some antioxidative systems in acid rain treated bean plants: Protective role of exogenous polyamines. Plant Science, 151: 59-66. https://doi.org/10.1016/S0168-9452(99)00197-1

80.Weisany, W., Sohrabi, Y., Heidari, G., Siosemardeh, A. and Ghassemi-Golezani, K. (2012). Changes in antioxidant enzymes activity and plant performance by salinity stress and zinc application in soybean (Glycine max L.). Plant Omics Journal, 5(2): 60-67.

81.Wu, F. and Zhang, G. (2002). Alleviation of cadmium-toxicity by application of zinc and ascorbic acid in barley. Journal of Plant Nutrition, 25: 2745-2761. https://doi.org/10.1081/PLN-120015536 